\title{
ON EFFORTS TO IMPROVE THE CONDITION OF THE TREASURY OF THE GRAND DUCHY OF LITHUANIA IN THE TIMES OF SIGISMUND THE OLD AND THE PERIOD OF MANAGEMENT BY JONAS JONAITIS ZABEREZINSKIS IN UŽNEMUNE்
}

\author{
Antoni K. Urmański
}

\begin{abstract}
The article presents an analysis of the activities of the Trakai palatine and land marshal of the Grand Duchy of Lithuania, Jonas Jonaitis Zaberezinskis (died 1538), as the administrator of state and private lands in Užnemune. The author analyses this figure's relations with the efforts initiated by Grand Duke of Lithuania Sigismund the Old and his wife Bona Sforza to improve the state's finances. Based on the work already done by previous authors and source data, the author tries to reconstruct the magnate groups that existed in the 1520s and 1530s, and also to analyse Zaberezinskis' economic administration in the region where most data has survived regarding his activities, i.e. in Užnemune, in the period from 1506 when Alytus and Simnas came under the jurisdiction of the Zaberezinskis family following the privilege of Alexander Jagiellon, until the death of Jonas Jonaitis Zaberezinskis in 1538.
\end{abstract}

Domestic and foreign policy of the Grand Duchy of Lithuania (GDL) in the times of Sigismund the Old has on numerous occasions been analysed in historical scientific literature, yet we still come across data that can broaden our knowledge of this topic even further. Polish chancellor Jan Chojeński gave a good description of the domestic situation in Lithuania in the beginning of the 1530s in his letter dated 30 July 1533 to the Polish deputy-chancellor, Piotr Tomicki. He wrote:

Negotia hic istius Ducatus negligentius curantur, forsan ideo, quod d[omi]ni palatinus et castellanus Vilnensis male sint affecti ob redemptionem bonorum ducalium de manibus eorum, quam parant domini nostri et iam dictus est dies ad ponendas litteras super Grodno, quae res turbavit non mediocriter d[ominem] castellanum Vilnensem, qui videtur nunc esse coniunctissimus cum d[omi]no palatino, cum quo in dies consultat [...] Summa rei tres occuparunt, hii et qui illis sunt addictissimi 
crudelem tyrranidem in alios exercent, clamor et ululatus usque ad caelum, nulla tamen fit iustitiae administratio, quae etiam sine effusione sanguinis, famae et bonorum privatione in quibusdam, fieri non posset, a quibus quin abhorreat clementia principis nostri, optime novit P[otes] tas V[estrae] $R .{ }^{1}$

Commenting on this excerpt from Chojeński's letter to Tomicki, the historian Władysław Pociecha wrote that Bona had resolved to put an end to the exploitative ways of the triumvirate of Albertas Goštautas (Olbracht Gasztołd), Jurgis and Jonas Radvila (Jerzy and Jan Radziwiłl). ${ }^{2}$ The grand duchess did not just become the owner of the largest holdings, but also introduced exemplary order into the state. She also won the respect of her subjects who sought protection from the lawlessness of the magnates.

Sources from the 1520 s-early 1530 s suggest that in the letter cited above, besides Goštautas (Lithuanian grand chancellor and Vilnius palatine from 1522) and the castellan Jurgis Radvila (Vilnius castellan from 1527, grand hetman from 1531), Chojeński most likely had in mind the existing Trakai palatine (from 1530/1531) ${ }^{3}$ and land marshal (from 1522) Jonas Jonaitis Zaberezinskis (Jan Janowicz Zabrzeziński) ${ }^{4}$ rather than Jonas Mikalojaitis Radvila (Jan Mikołajewicz Radziwiłł) (the existing cup-bearer and Kaunas starosta). ${ }^{5}$ It was Pociecha who constructed the hitherto-existing

${ }^{1}$ Królowa Bona (1494-1557). Czasy i ludzie odrodzenia, t. III: W. Pociecha, Księga IV: U szczytu władzy (1528-1539) (Poznań, 1958) (henceforth Królowa Bona, t. III), p. 237. Translation into Polish: ibid., pp. 109-110.

${ }^{2}$ Ibid., p. 110.

${ }^{3} \mathrm{He}$ is mentioned as such for the first time on 29 March 1531 (Urzędnicy Wielkiego Księstwa Litewskiego. Spisy, t. 2: Województwo trockie XIV-XVIII wiek, ed. A. Rachuba, H. Lulewicz, P. P. Romaniuk, A. Haratym (Warszawa, 2009), no. 1422; Lietuvos Metrika (1387-1546). Užrašymu knyga 25, eds. D. Antanavičius, A. Baliulis (Vilnius, 1998) (henceforth $L M$ 25, no. 41).

${ }^{4}$ The same could be presumed from his duties alone, and as he was the brother-in-law of J. Radvila himself, from a blood-ties perspective, he was no less worthy in that respect either. See: A. Urmański, 'Jan Janowicz Zabrzeziński, potomek Rymowida', Rocznik Instytutu Europy Środkowo-Wschodniej, Zeszyt 3: Polska - Litwa: stare i nowe problemy, 13 (2015), pp. 51-67. The observant reader will notice certain inaccuracies in the article: Jonas Jonaitis Zaberezinskis has been incorrectly attributed with the duty of being Grand Duchess Elena's court marshal, which was actually the post of Albertas Jonaitis Kločka (A. Winiarska, 'Kłoczko Wojciech Janowicz h. Ogończyk [zm. 1514]', PSB, 13 [1967], pp. 49-50).

${ }^{5}$ Urzędnicy Wielkiego Księstwa Litewskiego. Spisy, t. 1: Województwo wileńskie XIV-XVIII wiek, ed. A. Rachuba, H. Lulewicz, U. Jamialjanczyk, P. P. Romaniuk (Warszawa, 2004), p. 714; M. Michalewiczowa, 'Radziwiłł Jan h. Trąby (zm. 1542)”, PSB, 30 (1987), pp. 192-195. 
image of Zaberezinskis in historiography, according to whom the latter was a supporter of Bona Sforza's policy and of the union with Poland. ${ }^{6}$ Results of earlier research show that at least until 1530 it would be difficult to include him among Goštautas' political opponents and supporters of the union. ${ }^{7}$ Land management and social policy issues remained unanalysed.

Arriving in Lithuania for the first time in 1528, Bona Sforza, the wife of Sigismund the Old, embarked on implementing policy that would see the return of the ruler's holdings to his control. The ruler's decree released on 1 August foresaw the retraction of the grand duke's privilege to the magnates concerning management of manors for life, which sought to bring the state's treasury back into a satisfactory condition. ${ }^{8}$ That same year, in 1528 , representatives of the petty nobility, supported by the grand duchess, demanded that courts be introduced as per Poland's example. Goštautas was opposed to both these points from Sforza's programme: the return of land management into the ruler's jurisdiction, and the emancipation of the petty nobility from the magnates' courts. ${ }^{9}$

${ }^{6}$ Królowa Bona, t. III, pp. 63-66, 228.

${ }^{7}$ The political emancipation of the medium and petty nobility, which was more evident during the times of Sigismund Augustus, together with the external (Muscovy) factor, plus the dynasty's reorientation and the nobility's cultural closeness to Poland's political elite via various forms of cooperation, are considered the most important factors determining the union's 'maturity' (J. Bardach, 'Krewo i Lublin. Z problemów unii polsko-litewskiej', Studia z ustroju i prawa Wielkiego Księstwa Litewskiego XIV-XVII w. (Warszawa, 1970), pp. 11-67; Dzieje unii jagiellońskiej, t. II: O. Halecki, W XVI wieku (Kraków, 1920); G. Błaszczyk, Litwa na przełomie średniowiecza i nowożytności 1492-1569 (Poznań, 2002); J. Kiaupienè, 'Naród polityczny Wielkiego Księstwa Litewskiego a przestrzeń jagiellońska', Europa orientalis. Studia z Dziejów Europy Wschodniej i Państw Bałtyckich, 1 (2009), pp. 187-196), whereas the factor of the alleged pro-Polish magnates' programme has for a long time been overrated in literature (R. Petrauskas, 'Tarp kivirčų ir sutarimų: socialinès ir politinès Liublino unijos prielaidos', Liublino unija: ideja ir jos tęstinumas, eds. L. Glemža, R. Šmigelskytė-Stukienė (Vilnius, 2011), pp. 36-42).

${ }^{8}$ Królowa Bona, t. III, pp. 60-64.

${ }^{9}$ W. Pociecha, 'Bona Sforza d'Aragona (1494-1557)', PSB, 2 (1936), p. 289. In 1529, Goštautas sent Bona arguments against the introduction of a courts system as in Poland, which representatives of the nobility demanded already in 1528. The chancellor explained arguments against economic reforms in another memorial to the grand duchess, which has not survived (W. Pociecha, 'Gasztołd Olbracht h. Awdaniec (†1539)’, PSB, 7 (1949), p. 302). Aside from his polemical writings, the First Statute of Lithuania, prepared by figures in his circle, gives a 
Naturally, the following questions arose: Whose side did Zaberezinskis take once disagreements between the grand duchess and the Vilnius palatine became apparent? What was his position on the reforms? Are there grounds to speak about his political re-orientation at the turn of the $1520 \mathrm{~s}-1530 \mathrm{~s}$, when Jurgis Radvila united with Goštautas against Bona Sforza? Can he be depicted as a guard of the dynasty's interests from the exploitative ways of the other magnates and their lawlessness? In order to answer these questions, we shall try once again to look at the personal milieu of the grand duchess, and also analyse Zaberezinskis' economic administration in the region from where most data about his activities has survived, i.e. in Užnemune, ${ }^{10}$ in the period from 1506 when Alytus and Simnas came under the control of the Zaberezinskis family following the privilege of Alexander Jagiellon, until the death of Jonas Jonaitis Zaberezinskis in 1538. Pociecha has made the first step in this direction, but he used only a small amount of resource data. ${ }^{11}$ Jonas Reitelaitis, who wrote at around the same time (died in $1966,{ }^{12}$ the work is undated) did not discuss the links between the colonisation of Užnemunè and the ruler's policy. ${ }^{13}$

good indication of how Goštautas regarded the estates (magnates were the rulers' aides and partners in holding authority, the nobility were simply there to follow orders) (Pirmasis Lietuvos Statutas (1529 m.), eds. I. Valikonytė, S. Lazutka, E. Gudavičius (Vilnius, 2001)). See also: R. Petrauskas, 'Titulas ir valdžia: Lietuvos Didžiosios Kunigaikštystès didikų savimonès pokyčiai XVI amžiaus pirmojoje pusèje', Pirmasis Lietuvos statutas ir epocha, eds. I. Valikonytė, L. Steponavičienė (Vilnius, 2005), pp. 42-43.

${ }^{10}$ The word 'Užnemunè' (Занемонье) appears in a document dated 2 July 1522 (Lietuvos Metrika (1440-1523). Užrašymu knyga 10, eds. E. Banionis, A. Baliulis (Vilnius, 1997) (henceforth LM 10), no. 107), where it is used in a narrower sense than the present-day concept of Užnemune (only its southern part was included), and is more adequate to name the lands under Zaberezinskis' control than for example, Dzūkija (an ethnographic region in Lithuania's southeast), which has not been found in sources from that time; see also: J. Totoraitis, 'Būdingieji Sūduvos arba Užnemunès istorijos bruožai', Suvažiavimo darbai, 2 (1936) (Kaunas, 1937; reprinted in Rome, 1973), pp. 259-282.

${ }^{11}$ Królowa Bona, t. III, pp. 64-66.

12 B. Raitelaityte, 'Kunigas Jonas Reitelaitis - istorikas, Dzūkijos kraštotyrininkas', Lietuviu kataliku mokslo akademijos metraštis, 11 (1997), pp. 295-332.

13 J. Reitelaitis, Zaberezinskai (typewritten), Krikštonys (s. a.), 40 p. VUB RS, F102-603. 


\section{Bona Sforza's relations with the GDL magnates until the end of the $1530 \mathrm{~s}$}

Pociecha tried to reconstruct the composition of the group that supported Bona's policy. ${ }^{14}$ According to the author, it included bishops: John of the Lithuanian Dukes, Paulius Alšeniškis (Paweł Holszański) and the elected bishop Mikalojus Viežgaila (Mikołaj Wieżgajło), as well as Jonas Jonaitis Zaberezinskis, Stanislovas Stanislovaitis Kęsgaila (Stanisław Stanisławowicz Kieżgajło), Andrius Nemiraitis (Andrzej Niemirowicz), Petras Stanislovaitis Kiška (Piotr Stanisławowicz Kiszka), Aleksandras Chodkevičius (Aleksander Chodkiewicz) and Jonas Hlebavičius (Jan Hlebowicz). Nevertheless, we must look carefully at this author's conclusions. The people attributed to 'Bona's group' were included based on singular and not always sufficiently significant sources. ${ }^{15}$ Goštautas was probably the only magnate to have left polemic works from which we can make an assessment of his political standpoint. ${ }^{16}$ Other data, such as the ruler's appointment of incumbents, the granting of holdings, the engagement of children, sometimes letters, help us work out who maintained closer ties with whom and when, and who supported whom in expectation of a particular state or Church position.

In response to the requests from the Žemaitjan bailiffs, Bona promoted Stanislovas Petraitis Kiška to occupy the post of starosta of Žemaitija, vacated after the death of Stanislovas Stanislovaitis Kęsgaila in 1532. ${ }^{17}$ When his widow, Ona of the Kiška line, died that same year, the private Kęsgaila holdings (mostly in Žemaitija) came under the supervision of the Zaberezinskis, ${ }^{18}$ who, in accordance

${ }^{14}$ Królowa Bona, t. III, pp. 63-66.

15 The author himself notes that it was not only the expected supporters of the grand duchess' programme who placed their seal under her decree, but her opponent, A. Goštautas, too. For a revision of some of Pociecha's statements for the reconstruction of the political groups of the time, see A. Wyczański, Między kultura a polityka: sekretarze królewscy Zygmunta Starego (1506-1548) (Warszawa, 1990), pp. 151-172.

${ }^{16}$ Senoji Lietuvos literatūra, 5 knyga: Šešioliktojo amžiaus raštija, eds. A. Samulionis, R. Jurgelènaitè, D. Kuolys (Vilnius, 2000), pp. 31-54.

17 Lietuvos Metrika (1530-1536). Užrašymu knyga 17, eds. L. Karalius, D. Antanavičius (Vilnius, 2015) (henceforth LM 17), no. 278 (Krakow, 10 November 1532): 'и за жеданьемь [...] Боны [...] дали есьмо [...] Петру Станиславовичу староство жомоитское'; E. Saviščevas, Žemaitijos savivalda ir valdžios elitas 1409-1566 metais (Vilnius, 2010), p. 251.

${ }^{18} \mathrm{~K}$. Pietkiewicz, Kieżgajłowie i ich latyfundium do połowy XVI wieku (Poznań, 1982), s. 44; LM 17, no. 256. 
with the last will and testament of the deceased Žemaitijan starosta, had to hand over a third of this land to Bona, ${ }^{19}$ as Sigismund Augustus was still considered too young (the grand duchess is not mentioned in Kęsgaila's last will and testament). ${ }^{20}$

In the undated text by Stanisław Górski, written following the death of the Polish deputy-chancellor, Piotr Tomicki, we read:

Repellebat igitur regina, rege ex ea pendiente, ab honoribus publicis, magistratibus Regni, viros dignos ac bene meritos, quos Tomicius evehendos regi per nuntios ac litteras proponebat, commendabat et pro eis rogabat [...] Nominatim vero Andreae de Gorca praefecturam Vielunensem ademit [...] Gastoldo praefecturam Bielscensem, Georgio Radivilio praefecturam Grodnensem, eius nepoti Radivilo praefecturam Samogitiensem, Sapiehae palatinatum Vitebscensem, Zabrzesinskio patrimonium omne, aliis item alias possessiones, rege connivente, adimebat, quarum nonnullas pro se retinebat, alias vero praefecturas, episcopatus, palatinatus, castellanatus et cetera Regni officia publica ac privata, sacra et profana vendebat creaturis suis (sic eos vocabat) infimi status hominibus, ineptis, stupidis, flagitiosis, reipublicae penitus ignaris, omnibus his ex eius nutu pendentibus. ${ }^{21}$

According to this text by Górski, we would have to assume that Zaberezinskis did not belong to Bona's group, while the relinquishing of his 'whole patrimony' to the benefit of Sigismund Augustus was far from voluntary, like Pociecha thought. However, the text clearly exhibits an adverse tone in regards to Bona, and the author might have consciously distorted some things. Jonas Mikalojaitis Radvila had been the Žemaitjan starosta since 1535 up to his death, ${ }^{22}$ but Grigalius Grigalaitis Astikaitis (Grzegorz Ościkowicz) was greeted by this same title on 16 May $1539,{ }^{23}$ thus it is quite possible that Jonas Radvila had indeed been temporarily removed from this post.

19 Ibid., s. 87. The transfer of the entire Plateliai district, with the Plateliai, Gintiliškès, Gargždai, Kretinga and Palanga estates, and the Vawkavysk holdings: Mscibava, Zelva, Gajcuniškès, took place on 23 August 1534.

${ }^{20}$ Lietuvos Metrika (1528-1538). Užrašymu knyga 15, ed. A. Dubonis (Vilnius, 2002) (henceforth LM 15), no. 135 (1533-06): 'панъ троикии, староста жомоитскии [...] записаль третюю часть всихъ именеи своих отъчызных [...] сыну нашому, з Божее ласки королю молодому и великому князю его милости Жьккимонъту'; cf. Królowa Bona, t. III, p. 66.

${ }^{21}$ Acta Tomiciana, 17 (1535), ed. W. Pociecha, (Wrocław-Kraków-Poznań, 1966), no. 600.

${ }^{22}$ Lietuvos Metrika (1528-1547). 6-oji Teismy bylu knyga, eds. S. Lazutka, I. Valikonyte (Vilnius, 1995) (henceforth LM 6), no. 385, 405, 406, et al.; M. Michalewiczowa, 'Radziwiłł Jan h. Trąby', pp. 192-195; Urzędnicy WKL, t. I, p. 714.

${ }^{23}$ Lietuvos Metrika (1536-1539). Užrašymu knyga 20, eds. R. Ragauskienè, D. Antanavičius (Vilnius, 2009) (henceforth LM 20), no. 186. 
Meanwhile, the fact that Ivanas Bagdonaitis Sapiega (Iwan Bohdanowicz Sapieha) retained the palatinate of Vitebsk obviously has something to do with his prior appointment to the Podolia palatinate following the death of Jonušas Kostevičius (Janusz Kostewicz) (he had also been transferred from Vitebsk to Podolia), so it is hard to see how Ivanas Sapiega could have been wronged in this case. ${ }^{24}$

Górski writes that the 'whole patrimony', omne patrimonium, had been expropriated from Jonas Jonaitis Zaberezinskis. Before we take a deeper look at the adequacy of the predicate ademit, it is not difficult to check whether there was a basis for this reproach by examining the composition of the 'expropriated' holdings. According to a division of lands with his brother Jurgis Jonaitis on 4 January 1509, the younger sibling (Jonas) received the Alytus, Simnas and Volma estates, as well as the estate of Zabereze and people in Žamoidz (curia Zabrzezynye, vna cum hominibus qui sunt in Samagithia). ${ }^{25}$ Of these lands, the royal family took back Alytus and Simnas, while Volma and Zaberezine's estate was inherited by the offspring of Jonas Jonaitis Zaberezinskis - his son Jonas, and after his death, his daughter Ona. ${ }^{26}$

Is there more reliable data about the magnate groups under the reign of Sigismund the Old and Bona? In the conflict in the 1520s, the Radvilas backed Konstantinas Ostrogiškis (Konstanty Iwanowicz Ostrogski) against Albertas Goštautas, over which the latter even complained to Bona in his famous memorial from 2 June $1525 .{ }^{27}$ An expression of this Ostrogiškis-Radvila union

${ }^{24}$ Maria Michalewiczowa has accurately noted that regardless of the accusations aimed at him that gave rise to the famous case brought against him, Ivanas Sapieha did not fall out of grace with the ruler (M. Michalewiczowa, 'Sapieha (Sapieha, Sopieżyc, Sopiha) Iwan h. Lis (zm. 1546)’, PSB, 34 (1993), pp. 618-619).

${ }^{25} A G A D$, parchment 7440. From a document dated 2 July 1522, it would appear that 'Žomoidz' was the name of a settlement near Zabereze (LM 10, no. 107: ' $а$ онь напротивку того воеводе дал волост свою Жомоить, ито лежить над озером Ольсконом, которие ж люди хоживали сена косити к двору его Заберезину'); see also AGAD, parchment 7406 (1498/1499 Alexander Jagellon's privilege for Jonas Jurgaitis Zaberezinskis): 'Inscribimus [...] curiam Zabrzerzye in districtu Vilnensi circa fluvium Brzezyna sitam [...] cum hominibus Zmoyth dictis in districtu [Vilnensi] penes lacum Olkschn[o] sitis cum [omnibus] seruitys ipsorum.'

${ }^{26}$ Lietuvos vyriausiojo tribunolo sprendimai 1583-1655, compiled by V. Raudeliūnas, A. Baliulis (Vilnius, 1988), no. 7; A. Pleszczyński, Opis historycznostatystyczny parafii międzyrzeckiej (Warszawa, 1911), p. 40.

27 Acta Tomiciana, 7/2 (1925), ed. T. Działyński (Poznań, 1858), no. 36, p. 259: concepit quam maximum in me odium ruthenus ducaculus et inivit contra 
was the engagement of their children. The daughter of the Trakai castellan Jurgis Radvila, Ona, was meant to marry the son of the Trakai palatine, Konstantinas Ostrogiškis, Ilya. ${ }^{28}$ A similar arrangement was reached between Goštautas and Zaberezinskis regarding their children, Stanislovas Goštautas (Stanisław Gasztołd) and Ona Zaberezinskyte (Anna Zabrzezińska). ${ }^{29}$ It was also decided that in the future, S. Goštautas would take over Zaberezinskis' post in the Novahrudok palatinate. ${ }^{30}$

Albertas Goštautas and the grand duchess shared a common view when it came to entrenchment of the dynasty's positions, meaning the coronation of Sigismund Augustus. In fact, it could be that the ruler Bona envisaged was quite different from the legibus alligatus ideal monarch being formed within the chancellor's milieu. ${ }^{31}$ Yet their paths definitively took different courses once the revision of land

me secretam conspirationem cum domo Radivillorum. Translation into Lithuanian: Šešioliktojo amžiaus raštija, p. 33. Aside from the Radvila men, in this conflict Zbysław Wojtkowiak also attributes Grigalius Astikas, the prince of Slutsk Jurgis Olelkaitis, and Ivanas Bagdonaitis Sapiega to the group of Konstantinas Ostrogiškis' supporters (Z. Wojtkowiak, 'Ostrogski Konstanty Iwanowicz książę [ok. 1460-1530]', PSB, 24 (1979), pp. 487-488).

${ }^{28}$ M. Kuźmińska, 'Olbracht Marcinowicz Gasztołd', Ateneum Wileńskie, 4 (1927), s. 24. Papal permission was granted for this sacrament on 1 March 1524 (W. Pociecha, 'Barbara Radziwiłłówna (1520-1551)', PSB, 1 (1935), pp. 294-295).

${ }^{29}$ R. Ragauskienè, Barbora Radvilaitè (Vilnius, 1999), p. 72.

${ }^{30}$ Dzieje unii jagiellońskiej, t. II: O. Halecki, WXVI wieku (Kraków, 1920), p. 74.

${ }^{31}$ Aside from the First Statute of Lithuania, this concept was expressed in the declaration allegedly made by the Vilnius bishop Albertas Taboras (Wojciech Tabor) to Alexander Jagiellon, but actually prompted by Albertas Goštautas: Miłostywy korolu. Newinne na nas hnew twoy hospodarski byt, za pryczynoju nekotorych ludey, bo my protyw tebe, hospodara naszoho, nestoiali, alez my boronili praw y prywilejow naszych, szto bychmo pry nich zostali, a tak, miłostywy hospodaru, ia iako pastyr tutoszniaho państwa y wasz, powinenom toho stereczy, y tebe, hospodara naszoho, od toho otwodyty, aby ty, hospodar nasz, prawa naszy y listy swoi nam oderżat, a ieśli by choteł chto ich łamaty, boże msty każdomu takowemu. (Полное собрание русских летописей, т. 32: Хроники: Литовская и Жмойтская, и Быховца; Летописи: Баркулабовская, Аверки и Панцырного, ответственный редактор Б.А. Рыбаков (Москва, 1975), p. 171; Lietuvos Metraštis. Bychovco kronika, Translation, introduction and commentary by R. Jasas (Vilnius, 1971). Fryderyk Papée asserted that already in the times of Casimir Jagiellon, Lithuania's magnates copied their Polish brothers, dictating constitutional privileges to their ruler (F. Papée, Aleksander Jagiellończyk (Kraków, 2006), p. 13). For more on the attitude of Poland's politicians (J. Chojeński, P. Tomicki) towards the ruler's relations with the law, see A. Wyczański, Między kultura a polityka, pp. 254-256; to read about Bona's provisions, see: L. Kolankowski, Zygmunt August, wielki książę Litwy do roku 1548 (Lwów, 1913), p. 9. 
holdings began. From the earlier-cited letter from Chojeński dated 30 July 1533, we learn that Goštautas and Radvila became friends in the face of danger, and decided to uphold a common position on the ruling couple's land investments. ${ }^{32}$ The reason for the magnates' caution was clear: in the course of the 1520 s, it was revealed that both sides of the Radvila-Goštautas conflict had appropriated land in the ruler's holdings. ${ }^{33}$ The closer association between two of the most influential GDL magnates was not short-lived either, as their later correspondence shows. ${ }^{34}$ Their friendship was crowned by the wedding of their children, Stanislovas Goštautas and Barbora Radvilaitè (Barbara Radziwiłłówna), in Mūriniai Geranainiai, which belonged to the Goštautas line, on 18 May 1537 (or some days earlier), ${ }^{35}$ following the end of the Moscow campaign, having turned down Goštautas' prior arrangement reached with Jonas Jonaitis Zaberezinskis.

Who could the ruling couple turn to for support in Lithuania?

Pociecha, very knowledgeable in the history of this era, considered one person to be unreservedly devoted to the dynasty's interests, ${ }^{36}$ the son of Sigismund the Old, Vilnius bishop John of the Lithuanian Dukes. ${ }^{37}$ According to Jerzy Ochmański, he was 'hated by the influential Radvilas and many other magnates', 38

32 Jurgis Radvila informed the Polish chancellor Krzysztof Szydłowiecki about the reconciliation with the Vilnius palatine already in February 1529 (Królowa Bona, t. III, p. 46); cf. N. Asadauskienè, Kišku gimine $L D K X V-X V I I$ a. Genealoginis tyrimas (Vilnius, 2003), p. 138.

${ }^{33}$ Królowa Bona, t. III, pp. 45-46 (the Radvila family transferred some of the holdings they appropriated to Goštautas).

34 On 12 March 1536, Goštautas urged Jurgis Radvila to discuss a common position on the eve of the sejm (R. Petrauskas, 'Titulas ir valdžia', p. 42); two days later, the Vilnius palatine warned the Vilnius castellan not to support the candidacy of Jerzy Chwalczewski to the GDL Council of Lords, as he was Bona's placeman - Lietuvos kataliku dvasininkai XIV-XVI a., eds. V. Ališauskas, T. Jaszczołt, L. Jovaiša, M. Paknys (Vilnius, 2009) (henceforth $L K D$ ), no. 1053.

${ }^{35}$ W. Pociecha, 'Gasztołd Stanisław h. Awdaniec (†1542)’, PSB, t. VII (Kraków, 1949), p. 303.

${ }^{36}$ Królowa Bona, t. III, s. 64; In 1519, the ruler mandated the recently appointed Vilnius bishop to reconcile Mikalojus Mikalojaitis Radvila and Albertas Goštautas: есмо особно через листы наши жадали князя бискупа Виленского и панов рад наших, абы вашу млсть ку згоде привели (И. Малиновский, Сборник материалов, относящихся к истории Панов Рады Великого Княжества Литовского (Томск, 1901), р. 389).

${ }^{37}$ LKD, no. 796.

38 J. Ochmański, Biskupstwo wileńskie w średniowieczu. Ustrój i uposażenie (Poznań, 1972), p. 16; similarly, see: L. Kolankowski, Zygmunt August, p. 215. 
yet maintained friendly relations with Zaberezinskis who donated to the bishop a house and land in Vilnius on 26 October $1533 .{ }^{39}$ The Trakai palatine and land marshal Jonas Jonaitis Zaberezinskis, together with his son Jonas, the marshal,

considerantes Boni ac Illustrissimi principis domini Ioannis ex ducibus lithwanie Dei gratia Episcopi vilnensis tota officia beneuolentie et sincere amicitie pluraque et insignia opera nobis exhibita, cupientes sue paternitati gratos reddere, ac in res nostras multo maioris affectus eum efficere

gave the bishop a plot of land between the present-day Šv. Jono and Gaono/Universiteto streets

aream nostram totalem et cum nonnulis muris in Civitate vilnensi in acie platearum per transuersum iter habencium vna qua itur ad ecclesiam Sancti Spiritus, alteram qua itur ad Curiam Episcopi vilnensis consistentem

most likely, the square named after Konstantinas Sirvydas) and the brick 'Vincenzo' house (perhaps the name of the Italian architect who designed the house?) in front of the mentioned plot of land, i.e. on the corner of the Curia (now, Universiteto St) and Holy Spirit (now, Dominikonu St) streets, that Mikalojus Jurgaitis Zaberezinskis (the deceased nephew of the Trakai palatine) had bought from Bernard the goldsmith before the Vilnius city fire ${ }^{40}$ for a certain sum of copper coins

domumque muratam nuncupatam vincencii ex oposito habentem, quamquidem domum cum area et muro magnificus dominus Nicolaus Zabrzezinski in humanis agens nepos noster ex fratre, a quodam aurifice Bernardo ante vrbis vilnensis conflagrationem certa summa eris mercatus erat.

We also have data about an earlier episode of relations between the Vilnius bishop, Jonas, and Jonas Jonaitis Zaberezinskis. On 2 September 1523, the bishop, represented by the Krakow canon

39 The original parchment is kept in the Wróblewski Library Manuscript Department of the Lithuanian Academy of Sciences (abbreviated to MAVB RS, F6-145). The document was known to the 19th-century author Michał Homolick ('Katedra wileńska', Wizerunki i roztrząsania naukowe. Poczet nowy drugi, t. XIV (Wilno, 1840), pp. 5-81, here 13-14; see also: J. Bartoszewicz, Królewicze biskupi. Żywoty czterech kapłanów (Warszawa, 1851), p. 134; W. Przyałgowski, Żywoty biskupów wileńskich, t. I (Petersburg, 1960), p. 123). A slightly inaccurate translation of an excerpt from the document is in E. Laucevičius, B.R. Vitkauskiené, Lietuvos auksakalyste (Vilnius, 2001), p. 189.

${ }^{40}$ The Vilnius fire of 1530 is mentioned most often in literature (LKD, no. 827, 830i., 796, 1915, 2491). A register of fires in Vilnius: V. Drèma, Dingęs Vilnius (Vilnius, 1991), p. 16; R. Jasas, Lietuvos metraštis, p. 29 mentions the Vilnius fire of 1529. 
Jakub Staszkowski, in a case against the Vilnius capitula, went to trial against the canon Martynas Dušnikietis, claiming that the latter had vilified the former in front of Marshal Zaberezinskis, accusing the bishop of greed for the money and possessions of the notary Grzegorz from Lwówek, for which the bishop had put the notary in prison. ${ }^{41}$ Even before this event, certain amicable bonds had been established between the two, which the bishop wished to maintain.

During the course of the land revisions, and with the treasury often in critical condition in wartime, the land treasurer played a strategic role in any plans. All state funds had to go through him first. As Ludwik Kolankowski accurately noted, the ruler, not very trusting of the most powerful magnates' financial administration, was more inclined to entrust the treasury to lower-ranking persons. ${ }^{42} \mathrm{Up}$ to the rebellion of Mykolas Glinskis (Michał Glińksi), this position was held by Teodoras (Fedka) Chrebtavičius (Teodor Chrebtowicz), and in 1509 it was taken over by Bohušas Bohovitinavičius (Bohusz Bohowitynowicz), who soon stepped down. ${ }^{43}$ Special credit should go to Abraham Ezofowicz, a Jew from the Kyiv land, who converted to Orthodoxy in 1488. At the beginning of the reign of Sigismund the Old, Ezofowicz was promoted by the land marshal and Hrodno starosta Jonas Jurgaitis Zaberezinskis and the Vilnius bishop Albertas Taboras. The first admitted Ezofowicz to use the Leliwa coat of arms; ${ }^{44}$ and with the latter's approval, at the beginning of 1507, the proceeds of customs tax gathered from Kaunas were leased to Ezofowicz for two years. ${ }^{45}$ At the end of 1509, he assumed the post of land treasurer from Bohowitynowicz, and following the death of Albertas Jonaitis Kločka (Wojciech Janowicz Kłoczko) in 1514, Ezofowicz also served as the Kaunas starosta. The treasurer p. 16

${ }^{41}$ J. Kurczewski, Kościół Zamkowy czyli katedra wileńska, cz. III, Wilno, 1916,

${ }^{42}$ L. Kolankowski, Zygmunt August, s. 214; O. Halecki, 'Bohowitynowicz Bohusz Michał h. Korczak (Pelikan?) (†1530)', PSB, 2 (1936), pp. 226-227.

${ }^{43}$ W. Pociecha, 'Ezofowicz Rabinkowicz (Rabiczkowicz, Rebiczkowicz) Jan Abraham (†1519)', PSB, 6 (1948), p. 329.

${ }^{44}$ Confirmation of the adoption of Sigismund the Old of 1 July 1507 (W. Pociecha, ibid., p. 328).

45 Lietuvos Metrika (1499-1514). Užrašymu knyga 8, eds. A. Baliulis, R. Firkovičius and D. Antanavičius (Vilnius, 1995) (henceforth LM 8), no. 91. 
denied the revenue due to him earned from the Kaunas customs and district and put it towards financing the policy of Sigismund the Old. ${ }^{46}$ In the fateful year of 1514 , the bond for Kaunas Castle and the Rumšiškès estate provided the ruler with a loan of 10,000 florins. ${ }^{47}$ After the death of Ezofowicz in 1519, Bohowitynowicz again served as treasurer during the whole of the 1520s, and from 1530 Ivan Hornostaj assumed this post. Accompanying Sigismund the Old in Krakow, there he practically doubled for the Lithuanian grand chancellor. ${ }^{48}$

In light of these comments, in order to clarify Zaberezinskis' attitudes in terms of dynastic policy, the following writ from Sigismund the Old addressed to him and dated 29 October 1536, i.e. on the way from the GDL to the crown capital, is very significant:

Мовиль намъ подскарбии земскии, маршалокъ и писар нашъ, державъияа слонимскии и мъстибоговскии, дорсунишъскии и зельвеньскии панъ Иванъ Горностаи - wrote the ruler to the Trakai palatine - о том, што ж деи некоторыи панове рады нашы Великого Князства Литовского узвазнили ся на него и неприязни съ себе ему оказують, где ж тыми разы, едучы нам с панъства нашого Великого Князства Литовского до Коруны Польское, просиль насъ подскарбии нашъ, абыхмо в небытъности нашои господаръскои у томъ панъстве намомъ, полечыли его в ласкавою оборону и зычъливую приязнь твоеи милости, которою ся бы онъ повстанья напротивъку себе оных пановъ огражаль.

А так мы жедаемь твоеи милости, яко пана а рады нашое, абы твоя милость то для насъ, господара, уделаль, а его, подскарбего нашого, у в опеку и в оборону свою взяль, и в ласкавои приязни своеи его ховал, и в таковом узвазнени оных панов ему пораду и оборону чыниль, яко рада нама. A мы теж то ласкою нашою господаръскою отъдавати будемъ твоеи милости. ${ }^{49}$

It is not difficult to guess which magnate-driven antagonism Hornostaj had to have encountered whilst implementing the revision of holding borders. After the ruler left Vilnius on Friday 19 October 1536, he never met the Trakai palatine again. ${ }^{50}$ There are more letters

46 Similarly, in 1529 Bohowitynowicz covered a deficit of 820 kapa and 56 groschen from his own funds (W. Pociecha, Królowa Bona, t. III, p. 58).

${ }^{47}$ Z. Kiaupa, Kauno istorija, vol. I, Vilnius, 2010, p. 112; the treasurer Jan Boner played a similar role in Poland (W. Budka, 'Boner Jan (†1523)', PSB, 2 (1936), pp. 297-299).

${ }^{48}$ W. Pociecha, Królowa Bona, t. III, s. 67-68; A. Markiewicz, 'Hornostaj Iwan Ostafjewicz h. Hippocentaurus (zm. 1558)’, PSB, 9 (1961), p. 627.

${ }^{49}$ Lietuvos Metrika (1535-1537). Užrašymų knyga 19, ed. D. Vilimas (Vilnius, 2009) (henceforth LM 19), no. 250. W. Pociecha, Królowa Bona, t. III, pp. 37, 223.

${ }^{50}$ One of the last acts of the grand duke in Vilnius was the confirmation of the funding of a chapel in Vilnius Cathedral by the Vilnius palatine Mykolas 
from Sigismund the Old to Jonas Jonaitis Zaberezinskis from this time until the latter's death, aside from the recently cited request to look after the treasurer Hornostaj, ${ }^{51}$ though not all are relevant to our topic. It is significant that there is a note directly related to the ruler's holdings that was sent from Lviv in September 1537, where the petty nobility had turned against their ruler over dissatisfaction with Sigismund the Old and Bona Sforza's actions. ${ }^{52}$ The ruler received news that when the Vilnius castellan Jurgis Radvila had the Merkine estate under his control (i.e. around 20 years prior), in addition to his Seirijai and Mordasovas estates, he unlawfully appropriated the people, lands and lake of Merkine. The ruler ordered the Trakai palatine, who was also the keeper of Merkine at the time, to bring these lands back under the jurisdiction of Merkine, and to ensure the castellan did not try to appropriate them again. Later, in response to a request from the Council of Lords, the ruler decided to look into the matter himself when he arrived back in Lithuania, instructing Jonas Jonaitis Zaberezinskis not to pose any objections to Jurgis Radvila until he was present. ${ }^{53}$

\section{The activities of Jonas Jonaitis Zaberezinskis in Užnemunė: economics and policy}

It appears that simply carrying out the ruler's direct orders was not the only way for Zaberezinskis to realise his programme. In order to look at this problem more closely, we shall have to go back in history a little more.

Although the grand duchess visited Lithuania for the first time only in $1528,{ }^{54}$ data from this time suggests that her ties with representatives of the GDL ruling elite could have been established

Kęsgailaitis, dated 18 October 1536 . The confirmation was requested by the guardian of S. Stanislovaitis Kęsgaila's children, Jonas Jonaitis Zaberezinskis, regarding the chapel's funding by their ancestor Mykolas Kęsgailaitis (MAVB RS, F6-161). Sigismund the Old departed from Vilnius on this date: Królowa Bona, t. III, p. 237; A. Gąsiorowski, 'Itineraria dwóch ostatnich Jagiellonów', Studia historyczne, r. 16, z. 2 (61) (1973), pp. 249-275 (here, p. 266).

${ }^{51}$ VUB RS, F77-20; LM 25, no. 229; R. Jasas, Pergamentu katalogas (Vilnius, 1980), no. 413; MAVB RS, F43-16394; LM 20, no. 42, 59. In this period, the land marshal was undoubtedly one of the most frequent addressees of the grand duke.

${ }^{52}$ Read about the Lviv rokosz here: L. Kolankowski, Zygmunt August, p. 63 and further.

${ }^{53}$ Królowa Bona, t. III, p. 173; R. Ragauskienè, Barbora Radvilaitè, p. 52.

54 W. Pociecha, 'Bona Sforza d'Aragona (1494-1557)', p. 293; Bona visited the GDL three times: $1528-1529,1533-1536$ and $1540-1542$. 
practically since the beginning of her residency in Krakow. Ezofowicz, Bohowitynowicz and the court treasurer Iwan Andrejewicz were also present in Krakow in $1518 .{ }^{55}$ When on 19 April 1518, the marriage of Bona Sforza, the daughter of the Duke of Milan Galeazzo Sforza and Elisabeth of Aragon, to the King of Poland and Grand Duke of Lithuania, Sigismund the Old, after two years of his being a widower, took place in Krakow, the situation in the ruler's states was far from enviable. The GDL's war with Muscovy was still underway (it lasted from 1512 to 1522, in 1514 the Muscovites took Smolensk, in the summer of 1518 they attacked Polotsk), ${ }^{56}$ and defending themselves against the Tatars, ${ }^{57}$ the GDL was also preparing to go to war in Prussia (1519-1521). ${ }^{58}$ Sigismund the Old worded the situation quite aptly in a letter to the Polish lords:

Angustie sunt nobis undique, nam preter hanc calamitatem cum Tartaris adest altera cum Moscis in Lithuania, quorum ad quinquaginta milia illuc intrantes recta Vilnam contendebant. ${ }^{59}$

He had to find a way to finance all these military efforts.

So, that same year, in 1518 whilst still in Krakow, and from November when he was at a session of the Lithuanian Sejm in Brest, Sigismund mortgaged a great many estates for loans. ${ }^{60}$ Jonas

${ }^{55}$ Lietuvos Metrika (1511-1518). Užrašymu knyga 9, ed. K. Pietkiewicz (Vilnius, 2002) (henceforth LM 9), no. 724; Lietuvos Metrika (1518-1523). Irašų knyga 11, ed. A. Dubonis (Vilnius, 1997) (henceforth $L M 11$ ), no. $29=L M 10$, no. 18.

${ }^{56}$ M. Kuźmińska, 'Olbracht Marcinowicz Gasztołd', Ateneum Wileńskie, t. IV, z. 13 (1927), p. 365.

${ }^{57}$ See J. Ochmański, 'Organizacja obrony przed Tatarami w Wielkim Księstwie Litewskim', Studia i materiaty do historii wojskowości, t. V (1960), pp. 349-399 (especially 362-363); on 2 August 1519, at the battle at Sokal, Fryderyk Herbut, the father-in-law of Jonas Jurgaitis Iljiničius, was killed, among others (O. Łaszczyńska, 'Herburt Fryderyk [Frydrusz, Fredrusz] h. Pawęża albo Herburtowa (zm. 1519)', $P S B, 9$ (1961), p. 439).

58 Read here about the Prussian war and the GDL: B. Dundulis, 'Lietuva ir Ordino valstybės žlugimas (1466-1525 m.)', Lietuvos TSR aukštuju mokyklu mokslo darbai, Istorija, t. X (1969), pp. 159-168 (especially pp. 164-165); J. Tyszkiewicz, Tatarzy na Litwie $i$ w Polsce. Studia z dziejów XIII-XVIII w. (Warszawa, 1989), pp. 174-175, 187-200, 302 (the author's research shows that Tatars from Hrodna took part in the war against Prussia, where the starosta at the time was Jurgis Radvila); G. Błaszczyk, 'Radziwiłł Jerzy h. Trąby (1480-1541)', PSB, 30 (1987), p. 226: Maciej Strykowski's writings about the large role played by Jurgis Radvila and the Lithuanians in the war, according to the author, sound 'exceedingly optimistic'.

59 Acta Tomiciana, 5 (1519-1521), ed. T. Działyński (Poznań, 1855), no. 78.

${ }^{60}$ Królowa Bona, t. III, pp. 55-56. 
Jonaitis Zaberezinskis received Markovas and Daugai as collateral. ${ }^{61}$ During the same Brest Sejm, on 1 January 1519, for his merits he received Nemunaitis and Meteliai, which he had already overseen since his father's death. ${ }^{62}$ After two months, when the king was in Krakow, Zaberezinskis made over both estates to his wife, Sofija Radvilaite (Zofia Radziwiłłówna), on 10 March in Goniądz, together with Volma and Rohaczów, while Nemunaitis was to become a part of the dowry of their daughter, Ona. ${ }^{63}$

In 1520 in Torun, Sigismund the Old allowed Zaberezinskis to keep Merkinè as well. ${ }^{64}$ As the Zaberezinskis family had owned Alytus and Simnas since the times of Alexander Jagiellon, these additional land grants from Sigismund the Old and collateral pledges contributed to the formation of a larger holdings complex. This process is worth closer attention, as it demonstrates the land owner's focused activities.

The Alytus estate and Simnas were gifts, while the Nemunaitis estate was pledged as collateral for 2,000 florins by the Lithuanian grand duke Alexander Jagiellon to the land marshal and Hrodno starosta, Jonas Jurgaitis Zaberezinskis, on 5 July $1506 .{ }^{65}$

At the end of that same year, in a writ of confirmation from Sigismund the Old, it is indicated that some of the Alytus land and lakes were given by Alexander to the Trakai bailiff Michna Ivanovičius Podbijpienta (Michno Iwanowicz Podbipięta); and therefore, the hunter and estate stable master Martynas Chrebtavičius (Marcin Chrebtowicz), together with the Hrodno stable master Mykolas Senkavičius Brancas (Michał Senkowicz Braniec), subtracted the same amount of land and people from Nemunaitis to add to what Jonas Jurgaitis Zaberezinskis had lost from Alytus. In place of the Alytus lakes, the Hrodno starosta was given Lake Dusia. ${ }^{66}$

${ }^{61} L M 10$, no. $18,23=L M 11$, no. 29,39 ; he is mentioned as the supervisor of Daugai for the first time on 24 December 1518 ( $L M$ 25, no. 19).

${ }^{62}$ Lietuvos Metrika (1380-1584). Užrašymu knyga 1, eds. A. Baliulis, R. Firkovičius (Vilnius, 1998) (henceforth $L M$ 1), no. 38.

${ }^{63} A G A D$, parchment 7492; LM 19, no. 180; R. Ragauskienè, Barbora Radvilaite, p. 72 .

${ }^{64} L M$ 10, no. 42; LM 25, no. 19; LM 1, no. 38, 18; Urzędnicy WKL, t. 2, no. 110, 113; A. Černiauskas, H. Gudavičius, V. Vaitkevičius, Merkinès istorijos bruožai (Vilnius, 2004), pp. 153-154.

${ }^{65}$ LM 6, no. 29; J. Reitelaitis, Zaberezinskai, pp. 5-6.

${ }^{66}$ LM 8, no. 170; J. Reitelaitis, Zaberezinskai, pp. 6-10. Translation into Lithuanian (from the document collection of Leontovičius) of three writs of Alexander Jagiellon 
Sources did not offer much information on this region for around ten years, but by the end of the 1510 s, Jonas Jonaitis Zaberezinskis did become more active here. In order to bring a united complex of lands under his control, the Novahrudok palatine decided to buy the part of the Alytus estate that now belonged to the Trakai bailiff, Michna. Surviving documents show that Michna Podbijpienta (who lived in Trakai in $1488-1507$ ) ${ }^{67}$ had three sons: Jonas, Martynas and Fiodoras (Jan, Marcin and Fiodor). After the death of their father, each received a third of the holdings in the Alytus district, known as Užnemune (Занемонье). A confirmation from Sigismund the Old dated 2 July 1522 gives their description, based on Alexander Jagiellon's privilege to Michna. ${ }^{68}$ Jonas Podbijpienta sold his third to Jonas Jonaitis Zaberezinskis before the middle of 1519. ${ }^{69}$ The Vilnius palatine Albertas Goštautas received the other two brothers' shares: Fiodoras sold his part for 500 florins, while Martynas exchanged his share for an estate in the Darsūniškis district. The keeper of Merkine and Daugai, Zaberezinskis, swapped these two parts with Albertas Goštautas for the Žamoidz district near Lake Olskon. This area would have most likely been in the Ašmena district, as Zaberezinskis indicated that people would go there to cut hay for Zabereze's estate. ${ }^{70}$ Some time later, in the summer of 1522, he bought Žadiškès from Jonas and Martynas Podbijpienta. ${ }^{71}$ The Nedzviedz estate was right nearby, which Sigismund the Old had signed over to the Novahrudok palatine with five servitors and four fields (пустовщина, an abandoned piece of land), in which he settled five people from the Daugai holding. ${ }^{72}$ On 29 March 1524, a tithe was donated from both estates to the Alytus church. ${ }^{73}$

(16 June, 23 June, and 5 July 1506) which gives a list of the men transferred from Nemunaitis to Jonas Jurgaitis Zaberezinskis' Alytus estate, plus the land boundaries, as compiled by the mentioned commissioners.

${ }^{67}$ J. Reitelaitis, Zaberezinskai, p. 28, based on A. Boniecki.

${ }^{68}$ LM 10, no 107; a description of Alexander Jagiellon's privilege to M. Podbijpientas dated 9 August (1496) LM 1, no. 166.

\footnotetext{
${ }^{69} L M$ 1, no. 321.

${ }^{70}$ LM 10, no. 107.

${ }^{71}$ LM 1, no. 322 'Zodziszki' and 307.

${ }^{72} L M 1$, no. 350, undated.

${ }^{73}$ MAVB RS, F43-5367.
} 
The acquisition of the village of Tilvinčiai and five empty fields from Duke Andriejus Ivanovičius (Andrzej Iwanowicz) in $1528^{74}$ was the last purchase made by Jonas Jonaitis Zaberezinskis that we notice. From then, property starts to move in the other direction: several years later, the magnate started to distribute his lands to his servitors. This process reflected his relations with the petty nobility, who often worked as the magnate's estate officials and served as his local representatives in separate estates. These relations also illustrate a broader phenomenon - a transition from feudal bonds, where the petty and middle nobility were subordinated to the magnates' authority, to client-based mutual bonds. ${ }^{75} \mathrm{We}$ must keep in mind that the land holdings of the Zaberezinskis, as with other magnate family holdings, were scattered over an enormous territory. Aside from the Užnemunè complex, Jonas Jonaitis Zaberezinskis also had estates near Ašmena (with the family's roots in Zaberezine) and in Podlasie (its centre, the city of Międzyrzec). It was impossible to personally manage all these estates under such circumstances. We can note the existence of a noble class dependent on magnates in the social structure of the GDL. By living on their lords' estates, the nobles and servitors could look after their property and lands, and ensure taxes were being paid. When the ruler granted a certain holding to a magnate, the local inhabitants automatically started to serve their new master. It is from this layer of society that supervisors for these separate estate farms could have emerged. Also noticeable is the trend that a magnate's estate supervisor would travel from one administrative unit to the next, becoming their local representative at the new location. Take for example Leonas Kotovičius (Lew Kotowicz), the local regent of Jonas Jonaitis Zaberezinskis in Novahrudok, who later served in the same role in Trakai. ${ }^{76}$ Or Laurynas Sutkaitis Žakas (Wawrzyniec Sutkowicz Żak), initially the regent in Merkine, who was later promoted to serve as the Eišiškès flag-bearer. ${ }^{77}$

In any case, magnates, themselves recipients of grants from the monarch, would give this land with its respective workforce over

${ }^{74} L M$ 1, no. $317,339$.

${ }^{75}$ Lietuvos istorija, t. IV: J. Kiaupienè, R. Petrauskas, Nauji horizontai: dinastija, visuomene, valstybè. Lietuvos Didžioji Kunigaikštystè 1386-1529 m. (Vilnius, 2009), p. 481.

${ }^{76} L M 14$, no. 612; LM 19, no. 106.

${ }^{77} L M$ 6, no. 66; $L M$ 20, no. 10. 
to their servitors, who would see to its management. ${ }^{78}$ In the era being discussed, as per the European example, the idea developed in the GDL as well that it was profitable to transform land holdings received in return for service, according to fief law, into unrestricted ownership, where the directly involved parties could engage in the production of agricultural produce and establish folwarks. ${ }^{79}$

There are several examples of this phenomenon. The first is evident in the donation notice to the Alytus church from 1524. Zaberezinskis' noble and his estate's cup-bearer Paulius had to give a tithe to the Nedzviedzis estate near Žadiškès, which Zaberezinskis had temporarily signed over to him for management (Paulus noster nobilis et pincerna tenens terram olim Miedzwickij a nobis sibi concessam). ${ }^{80}$ The court books of Motiejus Albertaitis Kločka (Maciej Wojciechowicz Kłoczko) (the local regent in Merkine in the first half of the 1530s) reveal that there was a regent of Zaberezinskis by the same name in Nemunaitis. ${ }^{81}$ The same Paulius with his noble land was mentioned in 1535 as well. ${ }^{82}$

On 22 May 1535 in Vilnius, the Trakai palatine signed over the same Nedzviedz manor to his cup-bearer and deputy chamberlain Jonas Ivanauskas (Jan Iwanowski), on the condition that the latter would remain in his service until his death. ${ }^{83}$ Ivanauskas was mentioned among Hornostaj's entries regarding payments in late 1532early 1533: he was issued with seven uolektis $(60-65 \mathrm{~cm})$ of fabric (сукна парпранъскго). ${ }^{84}$ From another document description about Ivanauskas, we learn that he served as the scribe in the Drohiczyn land. This time Zaberezinskis had not only pledged as collateral the mentioned estate, but given it away as a gift. This is evident not just from the cited document, where the property has been made over to Ivanauskas, his wife and offspring, but also from the fact that the latter sold it to another one of Zaberezinskis' servitors, Ivanas Michailovičius (Iwan Michaiłowicz), one and a half years later. ${ }^{85}$

78 J. Ochmański, Moniwid i jego ród, pp. 62, 66.

79 J. Kiaupienè, R. Petrauskas, Nauji horizontai, p. 481.

${ }^{80}$ MAVB RS, F43-5367.

${ }^{81}$ LM 6, no. 166.

82 J. Reitelaitis, Zaberezinskai, pp. 32-34.

${ }^{83} L M 1$, no. 46 and 36.

${ }^{84}$ LM 15, no. 161.1; Jonas Jonaitis Zaberezinskis' scribe Jonas is mentioned on 20 September 1532 (LM 17, no. 256)

${ }^{85} L M 1$, no. 145 and 319. 
In a document description dated 19 October 1536, Michailovičius (perhaps the same Podbijpienta, the son of the Trakai bailiff?) is identified as the starosta of Merkine and Darsūniškis, and Zaberezinski's chamberlain. ${ }^{86}$ Already before then, in September 1535, in return for serving the Trakai palatine, Michailovičius received the Dubonosov folwark in the Alytus holding unit for as long as he lived, and in December of that same year the Žadiškès and 'Ozierzec estate's subjects' (poddanych dwora ozierzeckiego, probably the people from Tilvinčiai village, bought from the Ozierzec duke, A. Ivanovičius). ${ }^{87} \mathrm{So}$, Zaberezinskis' servitor, Michailovičius, received three properties in the Alytus district that had belonged to his master. And on 26 September 1540, he gave all of them to Bona. ${ }^{88}$

We should also examine the transactions made between the Trakai palatine and grand duchess. On 18 March 1534, Zaberezinskis sold Bona the Aniškiai estate in Alytus for 1,500 florins; however, he retained the right to use it until his death (on 5 July 1536, he signed over a tithe from this estate to the Alytus church) ${ }^{89}$ Probably the most important transaction between Zaberezinskis and Sigismund Augustus and Bona took place at the Vilnius Sejm on 2 February 1536: Alytus, Simnas and Nemunaitis were signed over to the ruler's family, but could remain used by the Trakai palatine until his death, who also became the Merkine and Punia holder. ${ }^{90}$ After his death, in 1549, all these properties that were in Bona's name were signed over to the wife of Sigismund Augustus, Barbora. ${ }^{91}$

Of most importance for this study is that the activities of the manager of Alytus did not end after the property was signed over to Bona and Sigismund Augustus. His actions in this sphere continued in the granting of fields and pieces of forest. Thus, new lands were being cultivated and plots of arable land in estates were expanded. In 1536, Zaberezinskis allocated a tract of forest ten valakas ( 20 ha) in size near the Rudamina dams to Petras Plikius (Piotr Łysy). ${ }^{92}$ On

86 Ibid., no. 145.

87 Ibid., no. 348, 327, 418; 317, 319.

88 Ibid., no. 67.

89 Ibid., no. 31; Królowa Bona, t. III, pp. 65, 228 (date corrected from 13 March 1532 to 18 March 1534); J. Reitelaitis, Zaberezinskai, p. 31; MAVB RS, F43-204, 1. 170v.

${ }^{90}$ LM 1, no. 503, 39, 18; Urzędnicy WKL, t. 2, no. 193; Królowa Bona, t. III, p. 65.

91 Urzędnicy WKL, t. 2, p. 77.

92 This person was mentioned on 18 December 1542 (LM 6, no. 385). 
7 June of that same year, he granted his Tatars Juchna and Janos Bazaravičius (Juchno and Janosz Bazarowicz) from Alytus a field, as before then they did not have sufficient land to be able to serve one term in the military. Before, on 22 June 1536, Zaberezinskis donated three fields to Andriejus Mitkovičius Bychovcas (Andrzej Mitkowicz Bychowiec) in the Daugai district; on 27 June he gave a piece of forest to the Merkine flag-bearers so that they could cultivate it into arable land, as well as 30 barrels of grain to sow on the edge of the Merkine forest near Lake Rymietis and the Rudamina stream; while on 1 November 1537, he gave Michna and Alekna Konstantinovičius (Michno and Olechno Konstantynowicz) a piece of forest near the River Kirsna. ${ }^{93}$ These grants are linked to the founding of the Rudamina, Karužai and Kirsnos villages. The last property sign-over mentioned here took place in Alytus, which clearly became its administrator's favourite residence (from the spring of 1535 to autumn, 1537 we know of seven documents that Jonas Jonaitis Zaberezinskis issued from Alytus, plus one from Nemunaitis and one in Punia). This is the last recorded location we have for the Trakai palatine.

The fate of the former main Zaberezinskis residence in Vilnius is symbolic as well. Just before his death, the Trakai palatine Zaberezinskis donated the gardens near his palace in the capital of the GDL to his servitor, Adomas Paleckis (Adam Palecki). ${ }^{94}$ Later, Paleckis sold the gardens to Jonas Mikalojaitis Radvila for 100 florins, who sold it to Bona for the same sum. The palace itself, 'in a place known as Lukiškès' (na miesthcu nazwanym Łukiszki), was given to the grand duchess by the last male from the Zaberezinskis family, the ruler's marshal and supervisor of Semeliškejs, Jonas Jonaitis Zaberezinskis the Younger. ${ }^{95}$

$$
* * *
$$

Is Pociecha right to attribute everything beneficial that was implemented in the Grand Duchy of Lithuania in the 1530s to Bona Sforza? The author was of the opinion that of the two Sigismunds,

93 J. Reitelaitis, Zaberezinskai, p. 35, 38; LM 25, no. 56; J. Totoraitis, Sūduvos Suvalkijos istorija (Kaunas, 1937), p. 74.

94 The description of the document issued in Zaberezine ( $L M$ 1, no. 214) has the problematic date of 27 September 1538 (perhaps this was the date the donation was actually confirmed), as Jonas Jonaitis Zaberezinskis was mentioned as having already died on 14 June 1538 ( $L M 20$, no. 113 and 114).

${ }^{95}$ LM 1, no. 214, 207, 185, 107, 101. 
the grand duchess' son and husband, one was too young, while the other was not determined or strict enough with the lawless magnates. Our sources give a poor reflection of the communication between Jonas Jonaitis Zaberezinskis and Bona. Land transaction documents do not reveal the motives behind the sanctioned actions. Nevertheless, the data we do have leads us to criticise Gorski's words aimed against the ruler, where he alleged that she appropriated private property illegitimately. The terms of relations between the Trakai palatine and the grand duchess are not clear, yet Sigismund the Old obviously trusted the land marshal: he was appointed to handle all the difficult land-related matters with magnates until his dying day. If during the conflict between Albertas Goštautas and Konstantinas Ostrogiškis in the 1520s Zaberezinskis took the side of the former, then by the 1530 s we come across significant indications in sources of his good relations with people from the ruling couple's circle (who were opposed to the grand chancellor, Goštautas), such as the land treasurer Iwan Hornostaj or Vilnius bishop, Jonas. Judging by all the available data, the Trakai palatine's actions were motivated by the goal of increasing the state treasury's income (internal colonisation did not end even after the land was signed over to the grand duke's family). Development of the land holdings complex was determined by its geographical situation: 1) it was closer to the capital than other estates; and 2) it was right near the River Nemunas, which was convenient for transporting agricultural products. Although it might appear that the Trakai palatine's actions were coordinated first of all with the ruler, it is actually more likely that it was indeed his wife, Grand Duchess Bona, who formed the land acquisitions programme.

Author Details

Antoni Kazimierz Urmański is a PhD student at Vytautas Magnus University. His academic interests focus on the nobility of the Grand Duchy of Lithuania in the times of Alexander Jagiellon and Sigismund the Old.

Address: Vytautas Magnus University, Donelaičio g. 52, Kaunas LT-44244

E-mail: aurmanski@gmail.com 


\section{References}

ALIŠAUSKAS, V., JASZCZOŁT, T., JOVAIŠA, L., PAKNYS, M. (eds.) Lietuvos kataliku dvasininkai XIV-XVI a., (Vilnius, 2009).

ASADAUSKIENE, N.N. Kišku gimine $L D K X V-X V I I$ a. Genealoginis tyrimas (Vilnius, 2003).

BARDACH, J. 'Krewo i Lublin. Z problemów unii polsko-litewskiej', in Studia z ustroju i prawa Wielkiego Księstwa Litewskiego XIV-XVII w. (Warszawa, 1970).

BARTOSZEWICZ, J. Królewicze biskupi. Żywoty czterech kaptanów (Warszawa, 1851).

BŁASZCZYK, G. Litwa na przelomie średniowiecza i nowożytności 1492-1569 (Poznań, 2002).

BŁASZCZYK, G. 'Radziwiłł Jerzy h. Trąby (1480-1541)', in Polski Stownik Biograficzny, 30 (1987).

BUDKA, W. 'Boner Jan († 1523)', in Polski Stownik Biograficzny, 2 (1936).

ČERNIAUSKAS, A., GUDAVIČIUS, H., VAITKEVIČIUS, V. Merkines istorijos bruožai (Vilnius, 2004).

DRĖMA, V. Dingęs Vilnius (Vilnius, 1991).

DUNDULIS, B. 'Lietuva ir Ordino valstybès žlugimas (1466-1525 m.)', in Lietuvos TSR aukštuju mokyklu mokslo darbai. Istorija, 10 (1969).

HALECKI, O. 'Bohowitynowicz Bohusz Michał h. Korczak (Pelikan?) († 1530)', in Polski Stownik Biograficzny, 2 (1936).

HALECKI, O. Dzieje unii jagiellońskiej. T. 2 (Kraków, 1920).

HOMOLICKI, M. 'Katedra wileńska', in Wizerunki $i$ roztrzasania naukowe. Poczet nowy drugi, 14 (1840).

LAUCEVIČIUS, E., VITKAUSKIENĖ, B.R. Lietuvos auksakalystė (Vilnius, 2001).

JASAS, R. Pergamentu katalogas (Vilnius, 1980).

KIAUPA, Z. Kauno istorija. I tomas: Nuo seniausiu laiku iki 1655 metu (Vilnius, 2010).

Lietuvos istorija. IV Tomas: KIAUPIENĖ, J., PETRAUSKAS, R., Nauji horizontai: dinastija, visuomenè, valstybè. Lietuvos Didžioji Kunigaikštystė 1386-1529 m. (Vilnius, 2009).

KIAUPIENĖ, J. 'Naród polityczny Wielkiego Księstwa Litewskiego a przestrzeń jagiellońska', in Europa orientalis. Studia z Dziejów Europy Wschodniej i Państw Battyckich, 1 (2009).

KOLANKOWSKI, L. Zygmunt August, wielki ksiąze Litwy do roku 1548 (Lwów, 1913).

KURCZEWSKI, J. Kościót Zamkowy, czyli katedra wileńska. Cz. 3 (Wilno, 1916).

KUŹMIŃSKA, M. 'Olbracht Marcinowicz Gasztołd', in Ateneum Wileńskie, 4 (1927), 5 (1928). 
ŁASZCZYŃSKA, O. 'Herburt Fryderyk (Frydrusz, Fredrusz) h. Pawęża albo Herburtowa (zm. 1519)', in Polski Stownik Biograficzny, 9 (1961).

MARKIEWICZ, A. 'Hornostaj Iwan Ostafjewicz h. Hippocentaurus (zm. 1558)', in Polski Słownik Biograficzny, 9 (1961).

MICHALEWICZOWA, M. 'Radziwiłł Jan h. Trąby (zm. 1542)', in Polski Słownik Biograficzny, 30 (1987).

MICHALEWICZOWA, M. 'Sapieha (Sapieha, Sopieżyc, Sopiha) Iwan h. Lis (zm. 1546)', in Polski Stownik Biograficzny, 34 (1993).

OCHMAŃSKI, J. Biskupstwo wileńskie w średniowieczu. Ustrój $i$ uposażenie (Poznań, 1972).

OCHMAŃSKI, J. 'Moniwid i jego ród', in Lituano-Slavica Posnaniensia. Studia historica, 9 (2003).

OCHMAŃSKI, J. 'Organizacja obrony przed Tatarami w Wielkim Księstwie Litewskim', in Studia i materiaty do historii wojskowości, 5 (1960).

PAPÉE, F. Aleksander Jagiellończyk (Kraków, 2006 (1949)).

PETRAUSKAS, R. 'Tarp kivirčų ir sutarimų: socialinès ir politinès Liublino unijos prielaidos', in L. Glemža, R. Šmigelskytė-Stukienè (eds.), Liublino unija: ideja ir jos tęstinumas (Vilnius, 2011).

PETRAUSKAS, R. 'Titulas ir valdžia: Lietuvos Didžiosios Kunigaikštystès didikų savimonès pokyčiai XVI amžiaus pirmojoje pusèje', in I. Valikonytė, L. Steponavičienè (eds.), Pirmasis Lietuvos statutas ir epocha (Vilnius, 2005).

PIETKIEWICZ, K. Kieżgajłowie i ich latyfundium do połowy XVI wieku (Poznań, 1982).

PLESZCZYŃSKI, A. Opis historyczno-statystyczny parafii międzyrzeckiej (Warszawa, 1911).

POCIECHA, W. 'Barbara Radziwiłłówna (1520-1551)', in Polski Słownik Biograficzny, 1 (1935).

POCIECHA, W. 'Bona Sforza d'Aragona (1494-1557)', in Polski Stownik Biograficzny, 2 (1936).

POCIECHA, W. 'Gasztołd Olbracht h. Awdaniec († 1539)', in Polski Słownik Biograficzny, 7 (1949).

POCIECHA, W. Królowa Bona (1494-1557). Czasy i ludzie odrodzenia. T. 3 (Poznań, 1958).

POCIECHA, W. 'Ezofowicz Rabinkowicz (Rabiczkowicz, Rebiczkowicz) Jan Abraham († 1519)’, in Polski Stownik Biograficzny, 6 (1948).

RAGAUSKIENĖ, R. Barbora Radvilaitè (Vilnius, 1999).

PRZYAŁGOWSKI, W. Żywoty biskupów wileńskich. T. 1 (Petersburg, 1960).

RAITELAITYTĖ, B. 'Kunigas Jonas Reitelaitis - istorikas, Dzūkijos kraštotyrininkas', in Lietuviu kataliku mokslo akademijos metraštis, 11 (1997).

TOTORAITIS, J. 'Būdingieji Sūduvos arba Užnemunės istorijos bruožai', in Suvažiavimo darbai, 2 (1936) (reprinted in Rome, 1973). 
TOTORAITIS, J. Sūduvos Suvalkijos istorija (Kaunas, 1937).

TYSZKIEWICZ, J. Tatarzy na Litwie $i w$ Polsce. Studia $z$ dziejów XIII-XVIII w. (Warszawa, 1989).

URMAŃSKI, A. 'Jan Janowicz Zabrzeziński, potomek Rymowida', in Rocznik Instytutu Europy Środkowo-Wschodniej, 13 (2015).

Urzędnicy Wielkiego Księstwa Litewskiego. Spisy. T. 1: Województwo wileńskie XIV-XVIII wiek, ed. A. Rachuba, H. Lulewicz, U. Jamialjanczyk, P. P. Romaniuk (Warszawa, 2004).

Urzędnicy Wielkiego Księstwa Litewskiego. Spisy. T. 2: Województwo trockie XIV-XVIII wiek, ed. A. Rachuba, H. Lulewicz, P. P. Romaniuk, A. Haratym (Warszawa, 2009),

WINIARSKA, A. 'Kłoczko Wojciech Janowicz h. Ogończyk (zm. 1514)', in Polski Słownik Biograficzny, 13 (1967).

WOJTKOWIAK, Z. 'Ostrogski Konstanty Iwanowicz książę (ok. 14601530)', in Polski Stownik Biograficzny, 24 (1979).

WYCZAŃSKI, A. Między kulturą a polityką: sekretarze królewscy Zygmunta Starego (1506-1548) (Warszawa, 1990). 


\title{
APIE PASTANGAS TAISYTI LIETUVOS DIDŽIOSIOS \\ KUNIGAIKŠTYSTĖS IŽDO BŪKLĘ ŽYGIMANTO SENOJO \\ LAIKAIS IR JONO JONAIČIO ZABEREZINSKIO VEIKLĄ UŽNEMUNĖJE
}

Santrauka

ANTONI K. URMAŃSKI

\begin{abstract}
Straipsnyje analizuojamas Trakų vaivados, Lietuvos Didžiosios Kunigaikštystės žemès maršalo Jono Jonaičio Zaberezinskio (mirusio 1538 m.) kaip valstybinių bei privačių valdų Dzūkijoje administratoriaus, santykis su Lietuvos didžiojo kunigaikščio Žygimanto Senojo ir jo žmonos Bonos Sforcos inicijuotomis pastangomis taisyti valstybės finansus. J. Jonaitis Zaberezinskis istoriografijoje žinomas kaip vienas iš pagrindinių didžiosios kunigaikštienès Bonos inspiruojamų ūkio reformų šalininkų, nepaisant to, kad jo amžininkas Krokuvos kanauninkas Stanislovas Gorskis (Stanisław Górski) mini ji tarp Lenkijos karalienès ir Lietuvos didžiosios kunigaikštienės nuskriaustujų asmenų. Remiantis anksčiau rašiusių autorių (Władysławo Pociechos, kraštotyrininko kunigo Jono Reitelaičio) darbais bei naujai surinktais šaltiniais, straipsnyje bandoma atsakyti i tokius klausimus. Kieno pusejje buvo J. Jonaitis Zaberezinskis prasidejus didžiosios kunigaikštienès Bonos ir Vilniaus vaivados A. Goštauto nesutarimams? Koks jo nusistatymas minètų reformų atžvilgiu? Ar galima kalbėti apie J. Jonaičio Zaberezinskio politinį persiorientavimą XVI a. trečiojo ir ketvirtojo dešimtmečių sandūroje, kai Jurgis Radvila susivienijo su A. Goštautu prieš didžiąą kunigaikštienę Boną? Ar tinka žemės maršalą vaizduoti kaip dinastijos interesų sargą nuo kitų didikų piktnaudžiavimo ir savivalès? Ieškant atsakymo ị šiuos klausimus straipsnyje bandoma atkurti XVI a. trečiajame ir ketvirtajame dešimtmečiais buvusias didikų grupuotes. Taip pat analizuojamas J. Jonaičio Zaberezinskio ūkio administravimas Dzūkijoje 1506-1538 m. laikotarpiu (nuo Alytaus ir Simno patekimo ị Zaberezinskių rankas po Aleksandro Jogailaičio dovanojimo iki J. Jonaičio Zaberezinskio mirties).
\end{abstract}

